\title{
Roles of Arbuscular Mycorrhizal Fungi on soil fertility and its importance in phytoremediation of polluted soil
}

Abdoulaye Fofana Fall ${ }^{1,2^{*}}$, Grace Nakabonge ${ }^{3}$, Joseph Ssekandi ${ }^{1}$, Hassna Founoune, Samue ${ }^{1}$ Obeng Apori ${ }^{1}$, Abibatou Ndiaye ${ }^{1}$, Arfang Badji ${ }^{5}$ and Khady Ngom $^{1}$

1 African Center of Excellence in Agroecology and Livelihood Systems, Faculty of agriculture, Uganda Martyrs University, abdoulaye.fofanal@stud.umu.ac.ug

2 Fungi Biotechnology Laboratory, Plant Biology Department, Cheikh Anta Diop University of Dakar (UCAD), Senegal;

3 College of Agriculture and Environmental Sciences, Makerere University, Kampala, Uganda; e-mail@email.com

4 ISRA_LNRPV, Laboratoire National de Recherches sur les productions Végétales (LNRPV), Dakar, Senegal; fhassna@yahoo.fr

5 Department of Agricultural Production, Makerere University, Kampala, Uganda; e-mail@e-mail.com

* Correspondence: abdoulaye.fofana@stud.umu.ac.ug

Abstract: A single paragraph Arbuscular mycorrhizal fungi (AMF) establish symbiotic relationships with many crops. These soil microbiotas improve the soil fertility through the soil physical, chemical and biological properties. extending the root absorbing area. In return, the symbiont receives plant carbohydrates for the completion of its life cycle. AMF also helps plants to cope with biotic and abiotic stresses such as extreme temperature, heavy metal, diseases, and pathogens. For soil physical properties, the mechanisms used by AMF are the production of a glycoprotein, glomalin, which creates a high quality of soil macro-aggregations. These macroaggregations control soil erosion, nutrients and organic matter losses. For soil chemical properties, AMF produce acids and an enzyme called phosphatase. This enzyme hydrolyzes the inorganic phosphorus and the rock phosphate (RP) hence making $P$ available in the soil for plant uptake. AMF also are involved in soil nitrogen, carbon and trace element cycling. Regarding the biological component of the soil, AMF influence the composition, diversity and activity of microbial communities in the hydrosphere. They also work in synergy with others soil microorganisms to improve soil fertility, plant growth and resistance against some diseases. In this review, we present the contribution of AMF on soil fertility and importance in polluted soils.

Keywords: Microorganisms; Macro-aggregation, Rock phosphate, Glomalin

\section{Introduction}

The most significant threats to soil function at global level are soil erosion, soil organic carbon, excessive use of input and nutrient imbalance [1]. The depletion of soil fertility in the world has increased due to unsustainable land management practices such as overgrazing, bush burning, continuous crop cultivations, and tillage practices [2]. However, inoculation with Vesicular Arbuscular Mycorrhizae (AMF) has been identified as an ecofriendly approach to improve soil fertility [3]. AMF are the most widespread soil microorganisms that form a symbiotic relationship with more than $80 \%$ of agricultural crops [4], except for few plant families such as Amaranthaceae, Brassicaceae, Cruciferae, Chenopodiaceae, Caryophyllaceae, Juncaceae, Cyperaceae and Polygonaceae which do not exhibit 
any association [5]. They can be found in various ecosystems worldwide [6]. AMF is a key component of the soil microbiota and belongs to the glomeromycota phylum. This phylum is divided into 3 classes (Archaeosporomycetes, Glomeromycetes and Paraglomeromycetes), 5 orders (Archaeosporales, Diversisporales, Gigasporales, Glomerales and Paraglomerales), 14 families, 29 genera and more than 240 species [7], [8]. Several species of AMF have been studied in the world, however, the most species use as model are: Funneliformis mosseae (previously known as Glomus mosseae), Gigaspora rosea, Gigaspora margarita, Gigaspora gigantea and Rhizophagus irregularis (previously known as Glomus intraradices and Glomus irregulare) [9]. AMF are not parasite but obligate symbionts that need a host plant to complete their life cycle. They improve crops productivity by increasing water and nutrients uptake such as nitrogen $(\mathrm{N})$, phosphorus $(\mathrm{P})$ and potassium (K) [10]. The increase of the host plant nutrients uptake is due to the characteristics of AMF mycelium. These mycelium or hyphae absorb nutrients by osmotrophy and explore more surface area compared to non-mycorrhizal roots [11]. In return, AMF benefit carbohydrates from the host plants [12]. AMF are an extremely ancient symbiosis, indeed, based on archeologic records it dates back to the appearance of terrestrial plants (460 million years ago) and would have accompanied vascular plants to colonize the terrestrial environment [13]. AMF do not only have an impact on plant growth and production but it has been also reported that they improve some soil characteristics such as soil aggregation, soil nutrients availability, water retention, microbial activities, nitrogen, carbon and phosphorus cycling and soil acidity correction [14]-[16]. Several studies have reported that they play a crucial role in plant resistance against biotic and abiotic stresses. The aim of this review is to summarize knowledge about AMF symbiosis, in particular the beneficial effects on soil. First, the role of AMF in soil physical, chemical and biological properties is considered. The contribution of AMF in soil aggregation, nutrients availability and boosting beneficial soil microorganism is discussed. Finally, the role diversity of interactions between AMF and other soil microorganisms are examined (Figure 1).

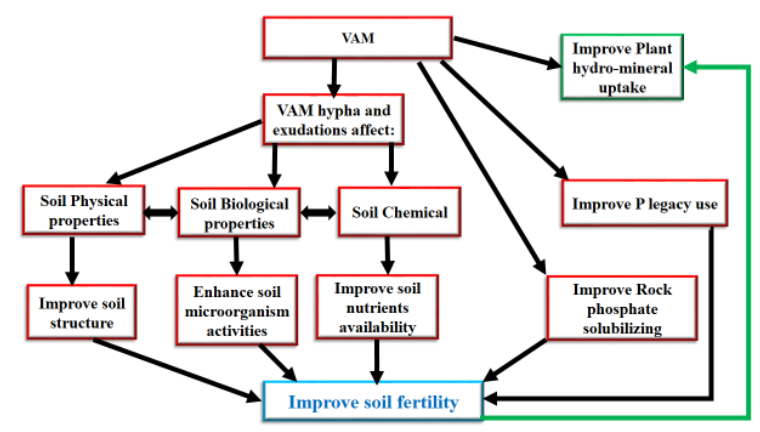

Figure 1. Effects of vesicular arbuscular mycorrhiza on improving soil fertility.

\section{Role of AMF on soil physical properties}

\subsection{Importance of AMF on soil structure}

AMF have a beneficial effect on soil structure. The AMF mycelium present in large quantities in soils, between 81 and $111 \mathrm{~m}$ per $\mathrm{cm} 3$ of soil [17]. These mycelia or hyphae have the property create stable soil aggregations. Mycorrhizal fungi act as a long-term soil binding agent through the production of a glycoprotein (glomalin) by the extramatrical mycelium [18], [19]. This glomalin is a hydrophobic, thermo-tolerant or heat-tolerant, resistant to high temperature of the soil. The hydrophobic character of the glamalin confers resistance of soil aggregations to water, the production of this substance reaches its maximum in senescent mycelia. This slowly biodegradable by bacteria and fungi in the soil. Its main function is to stabilize soil aggregations, like a glue that combines clay, silt 
and fine sand, with major effects on the physical properties of soils. The formation of soil aggregations is favored by glomalin [20], [21], acting like a glue binds together the soil micro-aggregations (diameter less than $250 \mu \mathrm{m}$ ) to form stable macro- aggregations [22], [23]. This soil macro- aggregations ensure better water infiltration, reducing surface runoff, control soil erosion, reduce nutrients and organic matter losses, increase gas exchange better retention of water and minerals, especially potassium therefore, improve crop productivity [16], [24]. In addition, the hyphae network is constantly renewing itself and the dead mycelium also preserves soil structure until decomposition [25]. The dead mycelium contributes to the stocks of organic matter and physical binder involved in soil aggregation [26]. All of these mechanisms reduce the risks of soil compaction and promote soil fertility [27]. It can be said that glomalin is very closely related to soil fertility.

\section{Role of AMF on soil chemical properties}

AMF fungal symbionts are recognized as being major microbial components in the development of the main biogeochemical cycles of soils ( $\mathrm{P}, \mathrm{N}$, and $\mathrm{C})$. This results in an improvement in the growth of mycorrhizal plants.

\subsection{Contribution of AMF on soil phosphorus availability}

Phosphorus is an essential element for plants. It is a component of many molecules such as Adenosine triphosphate (ATP), nucleotides, phospholipids, certain enzymes and coenzymes [28], [29]. Most soils contain large amounts of organic and inorganic phosphorus estimated between 200 and $3000 \mathrm{mg} / \mathrm{kg}$ of soil [30]. The accumulation of P in soils from fertilizers is known as legacy P (Sattari et al., 2012). This legacy P has the potential to play a key role in maintaining agricultural productivity [31]. It has been revealed that the accumulated $P$ in soils is sufficient to sustain crops yields worldwide for about 100 years [32]. Unfortunately, only a few quantities of this soil's $P$ is available for the plants [33]. The phosphorus is most often in the form of inorganic orthophosphate adsorbed to soil cations. Thus, the availability of soil $\mathrm{P}$ is affected by the presence of iron ( $\mathrm{Fe})$, calcium $(\mathrm{Ca})$ and aluminum ( $\mathrm{Al}$ ) oxides which fix phosphorus as iron phosphate (FePO4), tri-calcium phosphate (Ca3(PO4)2), and aluminum phosphate (AlPO4) [34]. Therefore, only a small proportion (less than 1\%) of the legacy P is available to plants [35]. Phosphorus is in fact taken in the form of orthophosphates (inorganic phosphate $\mathrm{Pi}$ ) by plants, but this mineral form of phosphorus is in limited quantity in the soil and, under the action of root sampling, areas are quickly created depletion around the roots due to a relatively slow supply of $\mathrm{P}$ from the solid phase of the soil and the low mobility of $\mathrm{P}$ in soils [36]. The reservoir of $\mathrm{P}$ must be hydrolyzed to make it available in the soil for plants uptake. AMF play an important role in improving P availability in the soil. Indeed, it is a P activator which can accelerate the process to transform $\mathrm{P}$ into bio-available forms via a range of chemical reactions and biological interactions [37]. To make the phosphorus available in the soil, AMF hydrolyze the organic P into inorganic phosphorus [38]. The mechanism used by AMF is linked to the production of enzymes named phosphatase [39]. This phosphatase release $\mathrm{P}$ from organic $\mathrm{P}$ or inorganic orthophosphate by hydrolyzing phosphoric acid monoesters into $\mathrm{P}$ ion and a molecule with a free hydroxyl group [40]. AMF can also solubilize inorganic phosphate into soluble forms through the processes of acidification, chelation, exchange reactions and production of organic acids, $\mathrm{H}^{+}$and metabolites [41], 
[42]. It is demonstrated that the metabolic activities of AMF produce alkaline phosphatases which cleave substrates present in the soil and make the phosphate accessible [43]. Moreover, the organic acid produced by AMF solubilizes insoluble mineral phosphate into a soluble form [44]. In addition, AMF help to release $P$ from rock phosphate fertilizer. Rock phosphate (RP) has a low effectiveness. This is due to when added as fertilizer only one part is accessible to the plants of and the remaining part is converted into insoluble fixed forms [45], [46]. Thus, AMF can solubilize insoluble phosphate from RP to make it available in the soil (Andrino et al., 2020). In fact, AMF convert the insoluble P into soluble forms through their production of acids during their metabolic activities [47].

\subsection{Contribution of AMF on soil nitrogen availability}

Like phosphorus, nitrogen $(\mathrm{N})$ is a vital component for plants. It is a constituent of phospholipids, coenzymes and amino acids [48]. In the soil, $\mathrm{N}$ is present in organic and mineral forms (nitrites, nitrates and ammonium ions). The ammonium form is weakly absorbed by plants that prefer nitrogen in the form of nitrate ( $\left.\mathrm{NO}^{3-}\right)$. AMF help to mobilize the inorganic form of nitrogen $\mathrm{NH}^{4+}$ from the soil [49]. The AMF mycelium is able to take up nitrogen in the form of ammonium ions $\left(\mathrm{NH}^{4+}\right)$ in the form of nitrates $\left(\mathrm{NO}^{3-}\right)$ and in the form of amino acids [50]-[52]. Indeed, AMF improve the degradation of organic matter in order to increase $\mathrm{N}$ bioavailability in the soil [53]. Nitrogen availability requires the activity of local transporters in the AMF hyphae. It has also been demonstrated that mycorrhizal associations could play a significant role in the decomposition and mineralization of plant organic matter and mobilize nutrients, particularly nitrogen, for the benefit of the host plant [54].

\subsection{Contribution of AMF on soil carbon cycle and $C$ sequestration}

AMF play an essential role in the global C cycle. In fact, AMF hyphae are involved in C translocation into the soil and provide a key link in the terrestrial C cycle [55]. Indeed, AMF are efficient agents to improve carbon sequestration in a mechanism of translocation C away from the high respiratory activity around the root and into the soil, including soil aggregations [56]. It has been demonstrated that mycorrhizal roots create a sink demand for carbon. When the atmospheric $\mathrm{CO}_{2}$ increase, the allocation of $\mathrm{C}$ from the plants to AMF also increase and stimulates the growth of AMF [57]. This $C$ demand is provided by the host plant from the $\mathrm{C}$ fixed through photosynthesis [16]. In addition, AMF extramatical hyphae represent 20 to $80 \%$ soil microbial biomass which consist $15 \%$ of soil organic $C$ [58], [59]. As we already discussed above, AMF play also a critical role in the formation and maintenance of soil aggregations through production of Glomalin. This glomalin protects organic matter from microbial degradation, increases the hydrophobicity and stability of macro-aggregations which control soil carbon loss and increase soil carbon stocks (C sequestration) [60], [61].

\subsection{Contribution of AMF on soil trace elements transfer}

Trace elements play roles in enzymatic activities involved in photosynthesis, oxidative respiration, protection against free radicals or even lipid biosynthesis[62]. It is known that AMF allow better absorption of low mobile trace elements in soils, such as potassium (K), 
calcium $(\mathrm{Ca})$, magnesium $(\mathrm{Mg})$, copper $(\mathrm{Cu})$, zinc $(\mathrm{Zn})$, iron $(\mathrm{Fe})$, manganese $(\mathrm{Mn})$ and cobalt (Co) [63], [64]. For instance, according to [65], the level of Zn, Fe and Mn is twice in mycorrhizal peanut plants compared to non-mycorrhizal plants. It has also been revealed that mycorrhizal inoculation improved $\mathrm{Zn}$ and $\mathrm{Cu}$ nutrition in soybeans and clover [66]. However, when some of these elements are present in high quantities and therefore possess a toxic character, the mycorrhization can play a role of protection of the plant, by a strong retention of these elements [67].

\section{Role of AMF on sol biological properties}

Microorganisms are one of the most important soil component. These microorganisms interact with each other and with their environment to contribute to the functioning of the soil and thus participate in the provision of ecosystem services necessary for our survival (plant production, purification of pollutants, etc.) [68]. Soil is therefore a very active biological reactor where diverse biochemical reactions and essential ecological processes happen (in particular the decomposition of organic matter, the biogeochemical cycles of the elements, etc.) [69]. The microbial activities in the soils contribute to its fertility through synergies between microorganisms, competition and parasitism (Topalović et al., 2021). Within the soil, AMF interact with wide range of microorganisms to better improve soil fertility. It has been demonstrated that the secretions of AMF influence the composition and activity of microbial communities in the rhizosphere [70]. The biological activities of AMF lead to the appearance of positive, neutral, or negative relationship between the AMF and other soil microorganisms.

\subsection{Positive interaction between AMF and soil microorganisms}

Many microbial components of the soil work synergistically with AMF, promoting growth and protection of plants [71], [72]. The positive interactions involve nutrient acquisition, biological control of root pathogens, improvement of plant tolerance to abiotic stress and soil fertility. AMF communities influence the physicochemical environment of the rhizosphere and control various soil microbial interactions [73]. Mycorrhization directly affects the quantity and quality of root exudates. These exudates influence the composition of the microflora of the rhizosphere [74]. AMF activity results in an increase in the diversity and abundance of soil parasite antagonists [75]. For instance, the presence of Glomus intraradices in the soil stimulate the production of an antibiotic by Pseudomonas fluorescens. This antibiotic known as 2,4-diacetylphloroglucinol, protect the host plants against Gaeumannomyces graminis [76]. Thus, this interaction in the rhizosphere can shape the Pseudomonas to remedy the imbalance caused by excessive proliferation of Gaeumannomyces graminis. Several studies have demonstrated that AMF increase the biomass of soil saprotrophic fungi, which allows the recycling of plant organic matter into mineral matter [77], [78]. It has been also revealed that AMF has a deletion effect on certain Gram-positive and Gram-negative bacteria groups and other fungi [79]. These changes in microbes affect the production of bioactive metabolites and the decomposition processes of organic matter [80]. AMF also interact with microorganisms in the rhizosphere and promote the development of bacteria which secrete organic acids responsible for dissolving phosphorus [81]. In acidic soil, AMF can exudate chelating agents that release phosphorus from the iron and aluminum molecules in the soil. In calcareous soil, AMF 
can acidify the soil thanks to organic acids, thus promoting the solubilization of phosphorus.

In addition, AMF can also interact other beneficial soil microorganisms such as Rhizobia, Plant Growth Promoting Rhizobacteria (PGPR) and Frankia. First, it is known that, AMF can work in synergy with nitrogen-fixing bacteria such as rhizobia to provide woody and crop legumes with essential soil nutrients [82]. For instance, the inoculation combination with AMF and Rhizobia is very effective to promote the growth of Faba bean compared to a sole inoculation [83]. A tripartite relationship can also be established between AMF, nitrogen-fixing bacteria and phosphorus solubilizing microorganisms to better help host plant to benefit from P [84], [85]. Second, the synergistic interaction between AMF and Frankia (nitrogen fixing actinobacteria) improve actinorhizal plants height, the numbers and dry weight of root nodules, leaf area, shoot height, total biomass, and $\mathrm{N}$ and P leaf contents. For instance, a study by [86] demonstrated that a combination of AMF, Frankia and ectomycorrhizal fungi increase Casuarina equisetifolia height. Regarding the impact of inoculation with AMF and Frankia combination on leaf area, shoot height, total biomass, and $\mathrm{N}$ and $\mathrm{P}$ leaf contents of Black alder trees (Alnus glutinosa), results revealed that a significant increase in these parameters compared to the non-inoculated control [87]. However, a rare case has shown a negative effect of dual inoculation between Frankia and AMF that has a depressive effect on plant biomass, probably due to a competition for carbohydrate between these two microorganisms. Lastly, AMF also interact with PGPR. This microorganism plays an important role in soil fertility and plant growth using various mechanisms such as ammonia production, $\mathrm{N}$ fixation, solubilization of mineral phosphate, and other essential nutrients, production of plant hormones, and control of phytopathogenic microorganisms [88]. Moreover, the combination of AMF and Bacillus subtilis increase also shoot and root dry weight, nodule number and leghemoglobin content than those inoculated with sole AMF or Bacillus subtilis [89]. This is due to the nitrate and nitrite reductase and nitrogenase activities and the contents in total lipids, phenols, fiber, and osmoprotectants such as glycine, betaine, and proline [89].

\section{Contribution of AMF in phytoremediation of polluted soils}

Although Although AMF play roles in soil biostabilisation, biofertilization and bioprotection, they can be used as curative tools in the biological treatment of polluted soils. This is called phytoremediation assisted by AMF [90]. Phytoremediation is a biological method of remediation and management of polluted soils [91]. It uses the natural capacity of plants and their associated microbiota to immobilize, contain and / or biodegrade environmental contaminants through various mechanisms such as phytostabilisation, phytoextraction and phyto-rhizodegradation [92]. This technology is judged to be in line with the sustainable development than physicochemical techniques, which despite their efficiency, lead to the alteration of the biological properties of the soil [93]. In addition to being ecological, phytoremediation has many advantages: less expensive, applicable to large areas of contaminated soils, easy to implement, generating little soil disturbance, exhibiting good landscape integration and good acceptance by the soil. 
Table 1 shows the effects of some AMF species on soil pollutants. AMF have been involved in mitigating the harmful effects of pollutants and make it possible to clean up soils contaminated by heavy metals [94], and aromatic hydrocarbons polycyclic (PAH) [95], pesticides [96], [97] and fungicides [98]. Heavy metals are a major agricultural soil constraint because they can have long-term effects on soil functioning [99]. They are known to alter important intrinsic proteins of plant membranes such as $\mathrm{H}^{+}-\mathrm{TPases}$ [100]. They induce the production of reactive oxygen species (ROS) which damage plant tissues [101] leading to chlorosis, growth retardation, root browning and other harmful effects on photosynthesis systems. According to [102], there are a series of mechanisms and symbiotic effect such as the metal binding capacity of fungal mycelium in the rhizosphere, which can help mycorrhizal plants to tolerate heavy metals. In fact, in the presence of toxic substances, AMF have the ability to change their hyphal architecture by promoting the linear growth of germinal hyphae. Amongst the strategies used include immobilization of metal compounds, precipitation of polyphosphate granules in the soil, adsorption to chitin in the fungal cell walls and chelation of heavy metals inside the fungus [103]. AMF can bind heavy metals beyond the plant rhizosphere by glomalin activities [104]. According to [105] association between saprophytic rhizosphere and AMF isolated from Cd-polluted soils plays an important role in the development and metal tolerance by plants and in soil bioremediation. AMF present multiple interests in the phytoremediation of polluted soils. They mitigate the phytotoxicity of pollutants through their ability to stimulate the defenses of plants against abiotic stresses such as pollutants. They promote the elimination of both metallic and organic pollutants. AMF contribute to the immobilization of Element-Trace Metal trace (ETM) in polluted soils by modifying the structure of the soil through the action of the mycelial network and the production of glomalin [106]. The production of glomalin stabilize the soil and immobilize metals and thus reduce metal stress in mycorrhizal roots [107]. Several studies have also demonstrated that AMF inoculation promotes the dissipation of persistent organic pollutants such as polycyclic aromatic hydrocarbons [108] and polychlorinated biphenyls [109]. In fact, AMF stimulate and modify the structure of microbial communities in the rhizosphere, particularly saprotrophic bacterial and fungal populations in the mycorrhizosphere. Thus, these saprotrophic bacterial and fungal biodegrade the organic pollutants compounds in the rhizosphere [108]. A study carried out by [110] revealed that that AMF (Glomus intraradices) associated with chicory roots improve the dissipation of anthracene by accumulating this polycyclic aromatic hydrocarbon in lipid globules, both root and fungal cells. 
Table 1: Examples of some AMF species that have impact on pollutants remediation

\begin{tabular}{|c|c|c|}
\hline Species & Adaptation properties & References \\
\hline Claroideoglomus etunicatum & $\begin{array}{l}\text { Element-Trace Metal (Lead, Zinc, } \\
\text { Copper and Cadmium) and fungicide }\end{array}$ & [111]; [96] \\
\hline Funneliformis constrictum, & $\begin{array}{l}\text { Species adapted to petroleum and } \\
\text { Atrazine }\end{array}$ & {$[112] ;[113]$} \\
\hline Funneliformis mosseae & $\begin{array}{l}\text { Species adapted to frequent soil } \\
\text { disturbances, such as petroleum, } \\
\text { fungicide; Element-Trace Metal }\end{array}$ & [114], [115], [116], [117] \\
\hline Glomus etinicatum & Play a role in Legacy P hydrolyze & [118] \\
\hline Glomus macrocarpum & Species adapted fungicide & [119], [120] \\
\hline Rhizophagus fasciculatus & Species adapted to Element-Trace Metal & [121] [122] \\
\hline Rhizophagus fasciculatus & Species adapted to Element-Trace Metal & [123] \\
\hline Rhizophagus irregularis & $\begin{array}{l}\text { Species adapted to Element-Trace Metal } \\
\text { And petroleum }\end{array}$ & [124] \\
\hline
\end{tabular}

\section{Conclusions}

Low-input sustainable cropping systems can only be viable through better knowledge and mastery of biological interactions in the agro-systems. Mycorrhizal fungi appear among the most important soil organisms to consider. AMF are directly involved in mineral nutrition, water absorption and protection against pollutants and certain biotic and abiotic stresses. The activities and interaction of AMF with other microorganism influence directly or indirectly the soil physical, chemical and biological component through their beneficial or detrimental activities. They improve soil fertility and mobilize the legacy $\mathrm{P}$ which play a vital role in maintaining agricultural productivity. However, more research is needed to evaluate the quantity of carbon fixed by the AMF, knowledge gap means that VAM cannot currently be included in the models of reduction the rate of atmospheric carbon there is a need to improve and apply analytical methods for evaluating parameters such as the quantity of carbon fixed by the AMF. This knowledge gap means that AMF cannot currently be included in the models of reduction the rate of atmospheric carbon. To remedy this situation, we recommend that laboratory, greenhouse and field experiments be conducted using rigorous standard protocols. This is how mycorrhizae will be able to contribute to the establishment of a new "green revolution" which, unlike the first, will this time be more in line with sustainable development.

Supplementary Materials: The following are available online at www.mdpi.com/xxx/s1, Figure S1: title, Table S1: title, Video S1: title.

Author Contributions: AFF contributed on inception of the paper, research and writing. GN contributed on inception and reviews of the paper. JS contributed on reviews. HF 
contributed on inception of the work. SOA contributed on write up. AN and $A B$ contributed on write up and review. KN reviewed the work

Funding: Regional Academic Exchange for Enhanced Skills in Fragile Ecosystems Management in Africa (REFORM).

Acknowledgments: The authors thank for Dr. Jude Ssebuwufu for supporting us.

Conflicts of Interest: The authors declare that they have no conflict of interest.

\section{Reference}

[1] L. Montanarella et al., “World's soils are under threat,” vol. 2, pp. 79-82, 2016, doi: 10.5194/soil-2-79-2016.

[2] O. Dewitte et al., "Harmonisation of the soil map of africa at the continental scale," Geoderma, vol. 211-212, pp. 138-153, Dec. 2013, doi: 10.1016/J.GEODERMA.2013.07.007.

[3] C. D. Cortivo et al., "Effects of Field Inoculation with VAM and Bacteria Consortia on Root Growth and Nutrients Uptake in Common Wheat," Sustain. 2018, Vol. 10, Page 3286, vol. 10, no. 9, p. 3286, Sep. 2018, doi: 10.3390/SU10093286.

[4] R. Prasad et al., "Introduction to mycorrhiza: Historical development," Mycorrhiza - Function, Diversity, State of the Art: Fourth Edition. Springer International Publishing, pp. 1-7, May 11, 2017, doi: 10.1007/978-3-319-53064-2_1.

[5] M. C. Brundrett, "Mycorrhizal associations and other means of nutrition of vascular plants: Understanding the global diversity of host plants by resolving conflicting information and developing reliable means of diagnosis," Plant and Soil, vol. 320, no. 1-2. pp. 37-77, Jul. 2009, doi: 10.1007/s11104-008-9877-9.

[6] "Mycorrhizal Symbiosis - Sally E. Smith, David J. Read - Google Books." https://books.google.co.ug/books?hl=en\&lr=\&id=qLciOJaG0C4C\&oi=fnd\&pg=PP1\&dq=smith+and+read+mycorrhizal+symb iosis\&ots=zruRIVYDqP\&sig=wYtxOCpg_T-ZKClYvwp3kbX-avc\&redir_esc=y\# $\mathrm{v}=$ onepage\&q=smith and read mycorrhizal symbiosis\&f=false (accessed Sep. 13, 2021).

[7] M. Krüger, C. Krüger, C. Walker, H. Stockinger, and A. Schüßler, "Phylogenetic reference data for systematics and phylotaxonomy of arbuscular mycorrhizal fungi from phylum to species level," New Phytol., vol. 193, no. 4, pp. 970-984, Mar. 2012, doi: 10.1111/j.1469-8137.2011.03962.x.

[8] D. Redecker and D. Redecker, "Specific PCR primers to identify arbuscular mycorrhizal fungi within colonized roots," Springer-Verlag, 2000.

[9] A. Schüssler and C. Walker, "The Glomeromycota: A Species List With New Families and New Gener," Glomeromycota A Species List With New Fam. New Gener, 2010.

[10] R. Anderson, D. Keshwani, A. Guru, H. Yang, S. Irmak, and J. Subbiah, “An integrated modeling framework for crop and biofuel systems using the DSSAT and GREET models," Environ. Model. Softw., vol. 108, pp. 40-50, 2018, doi: 10.1016/j.envsoft.2018.07.004.

[11] R. Duponnois et al., "Nurse shrubs increased the early growth of Cupressus seedlings by enhancing belowground mutualism and soil microbial activity," Soil Biol. Biochem., vol. 43, no. 10, pp. 2160-2168, Oct. 2011, doi: 10.1016/J.SOILBIO.2011.06.020.

[12] N. Diagne et al., "Effect of Plant Growth Promoting Rhizobacteria (PGPR) and Arbuscular Mycorrhizal Fungi (AMF) on Salt Stress Tolerance of Casuarina obesa (Miq.)," Front. Sustain. Food Syst., vol. 0, p. 266, Dec. 2020, doi: 10.3389/FSUFS.2020.601004.

[13] W. Remy, T. N. Taylor, H. Hass, and H. Kerp, “Four hundred-million-year-old vesicular arbuscular mycorrhizae," Proc. Natl. Acad. Sci., vol. 91, no. 25, pp. 11841-11843, Dec. 1994, doi: 10.1073/PNAS.91.25.11841. 
[14] B. Sadhana, “Arbuscular Mycorrhizal Fungi (AMF) as a Biofertilizer-a Review," 2014. [Online]. Available: http://www.ijcmas.com.

[15] A. Jamiołkowska, A. Księzniak, A. Gałązka, B. Hetman, M. Kopacki, and B. Skwaryło-Bednarz, "Impact of abiotic factors on development of the community of arbuscular mycorrhizal fungi in the soil: a review," Int. Agrophysics, vol. 32, no. 1, pp. 133140, Jan. 2018, doi: 10.1515/INTAG-2016-0090.

[16] M. Parihar et al., “The potential of arbuscular mycorrhizal fungi in C cycling: a review," Arch. Microbiol., vol. 202, no. 7, pp. 1581-1596, 2020, doi: 10.1007/s00203-020-01915-x.

[17] R. M. Miller, J. D. Jastrow, and D. R. Reinhardt, "External hyphal production of vesicular-arbuscular mycorrhizal fungi in pasture and tallgrass prairie communities," Oecologia 1995 1031, vol. 103, no. 1, pp. 17-23, Jul. 1995, doi: 10.1007/BF00328420.

[18] J. D. Driver, W. E. Holben, and M. C. Rillig, “Characterization of glomalin as a hyphal wall component of arbuscular mycorrhizal fungi," Soil Biol. Biochem., vol. 37, no. 1, pp. 101-106, Jan. 2005, doi: 10.1016/j.soilbio.2004.06.011.

[19] M. C. Rillig and D. L. Mummey, “Mycorrhizas and soil structure,” New Phytol., vol. 171, no. 1, pp. 41-53, Jul. 2006, doi: 10.1111/J.1469-8137.2006.01750.X.

[20] C. Mubekaphi, "Soil organic carbon, glomalin related soil protein and related physical properties after 15 years of different management practices in a subtropical region of South Africa.," 2019, Accessed: Sep. 14, 2021. [Online]. Available: https://researchspace.ukzn.ac.za/handle/10413/17109.

[21] D. Hu et al., "Arbuscular mycorrhizal symbiosis and achene mucilage have independent functions in seedling growth of a desert shrub," J. Plant Physiol., vol. 232, pp. 1-11, Jan. 2019, doi: 10.1016/j.jplph.2018.11.010.

[22] J. M. Tisdall, “Possible role of soil microorganisms in aggregation in soils," Plant Soil 1993 1591, vol. 159, no. 1, pp. 115-121, Feb. 1994, doi: 10.1007/BF00000100.

[23] J. Lehmann et al., "Persistence of soil organic carbon caused by functional complexity," Nat. Geosci. 2020 138, vol. 13, no. 8, pp. 529-534, Jul. 2020, doi: 10.1038/s41561-020-0612-3.

[24] J. Demenois, F. Rey, T. Ibanez, A. Stokes, and F. Carriconde, “Linkages between root traits, soil fungi and aggregate stability in tropical plant communities along a successional vegetation gradient," Plant Soil 2018 4241, vol. 424, no. 1, pp. 319-334, Jan. 2018, doi: 10.1007/S11104-017-3529-X.

[25] "Les mycorhizes: la nouvelle révolution verte - J. André Fortin, Christian Plenchette, Yves Piché - Google Books." https://books.google.co.ug/books?hl=en\&lr=\&id=_6kXEAAAQBAJ\&oi=fnd\&pg=PP1\&dq=Fortin,+J.+A.,+C.+Plenchette,+and +Y.+Piché.+\%22Les+Mycorhizes:+la+nouvelle+révolution+verte.+148.\%22+Québec,+Canada:+Éditions+multimondes+(2008). \&ots=jIfGviLow_\&sig=KZKYFiHf5LlW1PWiNmngBAKU8BQ\&redir_esc=y\#v=onepage\&q\&f=false (accessed Sep. 15, 2021).

[26] C. Hamel and C. Plenchette, "Implications of Past, Current, and Future Agricultural Practices for Mycorrhiza-Mediated Nutrient Flux," Mycorrhizal Mediat. Soil Fertil. Struct. Carbon Storage, pp. 175-186, Jan. 2017, doi: 10.1016/B978-0-12-8043127.00010-3.

[27] P. Jeffries, S. Gianinazzi, S. Perotto, K. Turnau, and J. M. Barea, "The contribution of arbuscular mycorrhizal fungi in sustainable maintenance of plant health and soil fertility," Biology and Fertility of Soils, vol. 37, no. 1. Springer Verlag, pp. 116, Jan. 01, 2003, doi: 10.1007/s00374-002-0546-5.

[28] M. Joho, M. Inouhe, H. Tohoyama, and T. Murayama, "Nickel resistance mechanisms in yeasts and other fungi," J. Ind. Microbiol., vol. 14, no. 2, pp. 164-168, Feb. 1995, doi: 10.1007/BF01569899.

[29] L. Agledal, M. Niere, and M. Ziegler, "The phosphate makes a difference: cellular functions of NADP," 
http://dx.doi.org/10.1179/174329210X12650506623122, vol. 15, no. 1, pp. 2-10, Feb. 2013, doi: $10.1179 / 174329210 \times 12650506623122$.

[30] A. F. Harrison and C.A.B. International., “Soil organic phosphorus : a review of world literature," p. $257,1987$.

[31] L. M. Condron, B. M. Spears, P. M. Haygarth, B. L. Turner, and A. E. Richardson, “Role of legacy phosphorus in improving global phosphorus-use efficiency," Environ. Dev., vol. 8, pp. 147-148, 2013, doi: 10.1016/j.envdev.2013.09.003.

[32] M. S. KHAN and A. ZAIDI, "Synergistic Effects of the Inoculation with Plant Growth-Promoting Rhizobacteria and an Arbuscular Mycorrhizal Fungus on the Performance of Wheat," TURKISH J. Agric. For., vol. 31, no. 6, pp. 355-362, Dec. 2007.

[33] T. Balemi and K. Negisho, "Management of soil phosphorus and plant adaptation mechanisms to phosphorus stress for sustainable crop production: a review," J. soil Sci. plant Nutr., vol. 12, no. 3, pp. 547-562, 2012, doi: 10.4067/S071895162012005000015 .

[34] A. Amanullah and M. Zakirullah, “Timing and Rate of Phosphorus Application Influence Maize Phenology, Yield and Profitability in Northwest Pakistan," Egypt. Acad. J. Biol. Sci. H. Bot., vol. 1, no. 1, pp. 29-39, Dec. 2010, doi: 10.21608/EAJBSH.2010.17014.

[35] M. Rodrigues, P. J. A. Withers, A. Soltangheisi, V. Vargas, M. Holzschuh, and P. S. Pavinato, “Tillage systems and cover crops affecting soil phosphorus bioavailability in Brazilian Cerrado Oxisols," Soil Tillage Res., vol. 205, p. 104770, Jan. 2021, doi: 10.1016/J.STILL.2020.104770.

[36] H. JAVOT, N. PUMPLIN, and M. J. HARRISON, “Phosphate in the arbuscular mycorrhizal symbiosis: transport properties and regulatory roles," Plant. Cell Environ., vol. 30, no. 3, pp. 310-322, Mar. 2007, doi: 10.1111/J.1365-3040.2006.01617.X.

[37] J. Zhu, M. Li, and M. Whelan, "Phosphorus activators contribute to legacy phosphorus availability in agricultural soils: A review," Sci. Total Environ., vol. 612, pp. 522-537, Jan. 2018, doi: 10.1016/j.scitotenv.2017.08.095.

[38] G. Feng, F. Zhang, X. Li, C. Tian, C. Tang, and Z. Rengel, "Improved tolerance of maize plants to salt stress by arbuscular mycorrhiza is related to higher accumulation of soluble sugars in roots," Mycorrhiza 2002 124, vol. 12, no. 4, pp. 185-190, 2002, doi: 10.1007/S00572-002-0170-0.

[39] J. C. Tarafdar and H. Marschner, "Phosphatase activity in the rhizosphere and hyphosphere of VA mycorrhizal wheat supplied with inorganic and organic phosphorus," Soil Biol. Biochem., vol. 26, no. 3, pp. 387-395, 1994, doi: 10.1016/00380717(94)90288-7.

[40] R. Othman and Q. A. Panhwar, "Phosphate-solubilizing bacteria improves nutrient uptake in aerobic rice," in Phosphate Solubilizing Microorganisms: Principles and Application of Microphos Technology, Springer International Publishing, 2014, pp. 207-224.

[41] L. Relwani, P. Krishna, and M. Sudhakara Reddy, “Effect of Carbon and Nitrogen Sources on Phosphate Solubilization by a Wild-Type Strain and UV-Induced Mutants of Aspergillus tubingensis," Curr. Microbiol. 2008 575, vol. 57, no. 5, pp. 401-406, Jul. 2008, doi: 10.1007/S00284-008-9212-Y.

[42] B. C. Behera, S. K. Singdevsachan, R. R. Mishra, S. K. Dutta, and H. N. Thatoi, “Diversity, mechanism and biotechnology of phosphate solubilising microorganism in mangrove-A review," Biocatal. Agric. Biotechnol., vol. 3, no. 2, pp. 97-110, Apr. 2014, doi: 10.1016/J.BCAB.2013.09.008.

[43] L. Liu et al., "Interactive Effects of Nitrogen and Phosphorus on Soil Microbial Communities in a Tropical Forest," PLoS One, vol. 8, no. 4, Apr. 2013, doi: 10.1371/journal.pone.0061188.

[44] F. Lapeyrie, “Oxalate synthesis from soil bicarbonate by the mycorrhizal fungusPaxillus involutus,” Plant Soil 1988 1101 , vol. 
110, no. 1, pp. 3-8, Aug. 1988, doi: 10.1007/BF02143532.

[45] V. Narsian and H. H. Patel, “Aspergillus aculeatus as a rock phosphate solubilizer,” Soil Biol. Biochem., vol. 32, no. 4, pp. 559565, Apr. 2000, doi: 10.1016/S0038-0717(99)00184-4.

[46] M. Billah, M. Khan, A. Bano, T. U. Hassan, A. Munir, and A. R. Gurmani, “Phosphorus and phosphate solubilizing bacteria: Keys for sustainable agriculture," Geomicrobiology Journal, vol. 36, no. 10. Taylor and Francis Inc., pp. 904-916, Nov. 26, 2019, doi: 10.1080/01490451.2019.1654043.

[47] G. Kalayu, "Phosphate solubilizing microorganisms: Promising approach as biofertilizers," Int. J. Agron., vol. 2019, 2019, doi: $10.1155 / 2019 / 4917256$.

[48] M. Hawkesford et al., “Functions of Macronutrients,” Marschner's Miner. Nutr. High. Plants Third Ed., pp. 135-189, Jan. 2012, doi: 10.1016/B978-0-12-384905-2.00006-6.

[49] L. Casieri et al., "Biotrophic transportome in mutualistic plant-fungal interactions," Mycorrhiza, vol. 23, no. 8. pp. 597-625, Nov. 2013, doi: 10.1007/s00572-013-0496-9.

[50] J. Jansa, S. T. Forczek, M. Rozmoš, D. Püschel, P. Bukovská, and H. Hršelová, “Arbuscular mycorrhiza and soil organic nitrogen: network of players and interactions," Chem. Biol. Technol. Agric. 2019 61, vol. 6, no. 1, pp. 1-10, Jun. 2019, doi: 10.1186/S40538-019-0147-2.

[51] N. Drechsler, P. E. Courty, D. Brulé, and R. Kunze, “Identification of arbuscular mycorrhiza-inducible Nitrate Transporter 1/Peptide Transporter Family (NPF) genes in rice," Mycorrhiza, vol. 28, no. 1, pp. 93-100, Jan. 2018, doi: 10.1007/s00572-0170802-z.

[52] A. Chen, M. Gu, S. Wang, J. Chen, and G. Xu, “Transport properties and regulatory roles of nitrogen in arbuscular mycorrhizal symbiosis," Semin. Cell Dev. Biol., vol. 74, pp. 80-88, Feb. 2018, doi: 10.1016/J.SEMCDB.2017.06.015.

[53] P. M. Huang, M. K. Wang, and C. Y. Chiu, "Soil mineral-organic matter-microbe interactions: Impacts on biogeochemical processes and biodiversity in soils," Pedobiologia (Jena)., vol. 49, no. 6, pp. 609-635, Nov. 2005, doi: 10.1016/J.PEDOBI.2005.06.006.

[54] H. Lambers, J. A. Raven, G. R. Shaver, and S. E. Smith, “Plant nutrient-acquisition strategies change with soil age," Trends in Ecology and Evolution, vol. 23, no. 2. pp. 95-103, Feb. 2008, doi: 10.1016/j.tree.2007.10.008.

[55] R. D. Finlay, “Ecological aspects of mycorrhizal symbiosis: with special emphasis on the functional diversity of interactions involving the extraradical mycelium," J. Exp. Bot., vol. 59, no. 5, pp. 1115-1126, Mar. 2008, doi: 10.1093/JXB/ERN059.

[56] Y. G. Zhu and R. M. Miller, “Carbon cycling by arbuscular mycorrhizal fungi in soil-plant systems," Trends Plant Sci., vol. 8, no. 9, pp. 407-409, Sep. 2003, doi: 10.1016/S1360-1385(03)00184-5.

[57] B. Drigo et al., "Shifting carbon flow from roots into associated microbial communities in response to elevated atmospheric CO2," Proc. Natl. Acad. Sci., vol. 107, no. 24, pp. 10938-10942, Jun. 2010, doi: 10.1073/PNAS.0912421107.

[58] Z. Kabir, I. P. O’Halloran, J. W. Fyles, and C. Hamel, “Seasonal changes of arbuscular mycorrhizal fungi as affected by tillage practices and fertilization : Hyphal density and mycorrhizal root colonization," Plant Soil 1997 1922, vol. 192, no. 2, pp. 285293, 1997, doi: 10.1023/A:1004205828485.

[59] J. Leake et al., “Downloaded from cdnsciencepub," Can. J. Bot, vol. 82, pp. 1016-1045, 2004, doi: 10.1139/B04-060.

[60] G. W. T. Wilson, C. W. Rice, M. C. Rillig, A. Springer, and D. C. Hartnett, "Soil aggregation and carbon sequestration are tightly correlated with the abundance of arbuscular mycorrhizal fungi: results from long-term field experiments," Ecol. Lett., vol. 12, no. 5, pp. 452-461, May 2009, doi: 10.1111/J.1461-0248.2009.01303.X. 
[61] M. C. Rillig, N. F. Mardatin, E. F. Leifheit, and P. M. Antunes, “Mycelium of arbuscular mycorrhizal fungi increases soil water repellency and is sufficient to maintain water-stable soil aggregates," Soil Biol. Biochem., vol. 42, no. 7, pp. 1189-1191, Jul. 2010, doi: 10.1016/J.SOILBIO.2010.03.027.

[62] J. A. Dominguez-Nuñez, B. Benito, M. Berrocal-Lobo, and A. Albanesi, "Mycorrhizal Fungi: Role in the Solubilization of Potassium," Potassium Solubilizing Microorg. Sustain. Agric., pp. 77-98, Jan. 2016, doi: 10.1007/978-81-322-2776-2_6.

[63] K. Garcia, J. Doidy, S. D. Zimmermann, D. Wipf, and P. E. Courty, “Take a Trip Through the Plant and Fungal Transportome of Mycorrhiza," Trends Plant Sci., vol. 21, no. 11, pp. 937-950, Nov. 2016, doi: 10.1016/J.TPLANTS.2016.07.010.

[64] A. Hashem et al., "Arbuscular mycorrhizal fungi regulate the oxidative system, hormones and ionic equilibrium to trigger salt stress tolerance in Cucumis sativus L.," Saudi J. Biol. Sci., vol. 25, no. 6, pp. 1102-1114, Sep. 2018, doi: 10.1016/J.SJBS.2018.03.009.

[65] K. R. Krishna and D. J. Bagyaraj, “Growth and nutrient uptake of peanut inoculated with the mycorrhizal fungusGlomus fasciculatum compared with non-inoculated ones," Plant Soil 1984 772, vol. 77, no. 2, pp. 405-408, Jun. 1984, doi: 10.1007/BF02182946.

[66] M. M. Schoeneberger, R. J. Volk, and C. B. Davey, “Selection of Reference Plants and Methods for Estimating N2 Fixation in Mycorrhizal Leguminous Plants," Soil Sci. Soc. Am. J., vol. 53, no. 5, pp. 1425-1429, Sep. 1989, doi: 10.2136/SSSAJ1989.03615995005300050020X.

[67] A. Liu, C. Hamel, R. I. Hamilton, B. L. Ma, and D. L. Smith, “Acquisition of Cu, Zn, Mn and Fe by mycorrhizal maize (Zea mays L.) grown in soil at different P and micronutrient levels," Mycorrhiza 2000 96, vol. 9, no. 6, pp. 331-336, 2000, doi: $10.1007 /$ S005720050277.

[68] U. N. Nielsen, E. Ayres, D. H. Wall, and R. D. Bardgett, “Soil biodiversity and carbon cycling: a review and synthesis of studies examining diversity-function relationships," Eur. J. Soil Sci., vol. 62, no. 1, pp. 105-116, Feb. 2011, doi: 10.1111/J.13652389.2010.01314.X.

[69] M. O. Gessner et al., “Diversity meets decomposition,” Trends Ecol. Evol., vol. 25, no. 6, pp. 372-380, Jun. 2010, doi: 10.1016/J.TREE.2010.01.010.

[70] S. D. Veresoglou and M. C. Rillig, “Community ecology Suppression of fungal and nematode plant pathogens through arbuscular mycorrhizal fungi," doi: 10.1098/rsbl.2011.0874.

[71] J. M. Barea, R. Azcón, and C. Azcón-Aguilar, "Mycorrhizosphere interactions to improve plant fitness and soil quality," Antonie van Leeuwenhoek, Int. J. Gen. Mol. Microbiol., vol. 81, no. 1-4, pp. 343-351, 2002, doi: 10.1023/A:1020588701325.

[72] M. Gryndler, "Interactions of arbuscular mycorrhizal fungi with other soil organisms," Arbuscular Mycorrhizas Physiol. Funct., pp. 239-262, 2000, doi: 10.1007/978-94-017-0776-3_11.

[73] A. Alimi, R. Adeleke, and A. Moteetee, "Soil environmental factors shape the rhizosphere arbuscular mycorrhizal fungal communities in South African indigenous legumes (Fabaceae)," Biodiversitas J. Biol. Divers., vol. 22, no. 5, pp. 2466-2476, Apr. 2021, doi: 10.13057/BIODIV/D220503.

[74] P. Marschner, D. Crowley, \& Ching, and H. Yang, “Development of specific rhizosphere bacterial communities in relation to plant species, nutrition and soil type," 2004.

[75] R. G. Linderman, “Effects of Mycorrhizas on Plant Tolerance to Diseases," Arbuscular Mycorrhizas Physiol. Funct., pp. 345365, 2000, doi: 10.1007/978-94-017-0776-3_15.

[76] X. Ma, W. Luo, J. Li, and F. Wu, “Arbuscular mycorrhizal fungi increase both concentrations and bioavilability of $\mathrm{Zn}$ in wheat 
(Triticum aestivum L) grain on Zn-spiked soils," Appl. Soil Ecol., vol. 135, pp. 91-97, Mar. 2019, doi: 10.1016/J.APSOIL.2018.11.007.

[77] A. Albertsen, S. Ravnskov, H. Green, D. F. Jensen, and J. Larsen, "Interactions between the external mycelium of the mycorrhizal fungus Glomus intraradices and other soil microorganisms as affected by organic matter," Soil Biol. Biochem., vol. 38, no. 5, pp. 1008-1014, May 2006, doi: 10.1016/j.soilbio.2005.08.015.

[78] A. Carteron, M. Beigas, S. Joly, B. L. Turner, and E. Laliberté, “Temperate Forests Dominated by Arbuscular or Ectomycorrhizal Fungi Are Characterized by Strong Shifts from Saprotrophic to Mycorrhizal Fungi with Increasing Soil Depth," Microb. Ecol., vol. 82, no. 2, pp. 377-390, Aug. 2021, doi: 10.1007/s00248-020-01540-7.

[79] M. Welc, S. Ravnskov, B. Kieliszewska-Rokicka, and J. Larsen, "Suppression of other soil microorganisms by mycelium of arbuscular mycorrhizal fungi in root-free soil," Soil Biol. Biochem., vol. 42, no. 9, pp. 1534-1540, 2010, doi: 10.1016/j.soilbio.2010.05.024.

[80] M. W. I. Schmidt et al., "Persistence of soil organic matter as an ecosystem property,” Nat. 2011 4787367, vol. 478, no. 7367, pp. 49-56, Oct. 2011, doi: 10.1038/nature10386.

[81] H. Moreira, S. I. A. Pereira, A. Vega, P. M. L. Castro, and A. P. G. C. Marques, “Synergistic effects of arbuscular mycorrhizal fungi and plant growth-promoting bacteria benefit maize growth under increasing soil salinity," J. Environ. Manage., vol. 257, Mar. 2020, doi: 10.1016/j.jenvman.2019.109982.

[82] L. J. C. Xavier and J. J. Germida, "Response of lentil under controlled conditions to co-inoculation with arbuscular mycorrhizal fungi and rhizobia varying in efficacy," Soil Biol. Biochem., vol. 34, no. 2, pp. 181-188, Feb. 2002, doi: 10.1016/S0038-0717(01)00165-1.

[83] L. Chatarpaul, P. Chakravarty, and P. Subramaniam, “Studies in tetrapartite symbioses," Plant Soil 1989 1181, vol. 118, no. 1, pp. 145-150, Aug. 1989, doi: 10.1007/BF02232800.

[84] M. E. Afkhami and J. R. Stinchcombe, "Multiple mutualist effects on genomewide expression in the tripartite association between Medicago truncatula, nitrogen-fixing bacteria and mycorrhizal fungi," Mol. Ecol., vol. 25, no. 19, pp. 4946-4962, Oct. 2016, doi: 10.1111/MEC.13809/FORMAT/PDF.

[85] S. Nacoon, S. Jogloy, N. Riddech, W. Mongkolthanaruk, T. W. Kuyper, and S. Boonlue, "Interaction between Phosphate Solubilizing Bacteria and Arbuscular Mycorrhizal Fungi on Growth Promotion and Tuber Inulin Content of Helianthus tuberosus L," Sci. Reports 2020 101, vol. 10, no. 1, pp. 1-10, Mar. 2020, doi: 10.1038/s41598-020-61846-x.

[86] M. Brundett et al., "Casuarina in Africa: Distribution, role and importance of arbuscular mycorrhizal, ectomycorrhizal fungi and Frankia on plant development," J. Environ. Manage., vol. 128, pp. 204-209, 2013, doi: 10.1016/j.jenvman.2013.05.009.

[87] R. S. Oliveira, P. M. L. Castro, J. C. Dodd, and M. Vosátka, “Synergistic effect of Glomus intraradices and Frankia spp. on the growth and stress recovery of Alnus glutinosa in an alkaline anthropogenic sediment," Chemosphere, vol. 60, no. 10, pp. 14621470, 2005, doi: 10.1016/j.chemosphere.2005.01.038.

[88] M. Ahemad and M. Kibret, "Mechanisms and applications of plant growth promoting rhizobacteria: Current perspective," J. King Saud Univ. - Sci., vol. 26, no. 1, pp. 1-20, 2014, doi: 10.1016/j.jksus.2013.05.001.

[89] A. Hashem, E. F. Abd_Allah, A. A. Alqarawi, R. Radhakrishnan, and A. Kumar, "Plant defense approach of Bacillus subtilis (BERA 71) against Macrophomina phaseolina (Tassi) Goid in mung bean," http://mc.manuscriptcentral.com/tjpi, vol. 12, no. 1, pp. 390-401, 2017, doi: 10.1080/17429145.2017.1373871.

[90] S. E. D. Hassan, E. Boon, M. St-Arnaud, and M. Hijri, “Molecular biodiversity of arbuscular mycorrhizal fungi in trace metal- 
polluted soils," Mol. Ecol., vol. 20, no. 16, pp. 3469-3483, Aug. 2011, doi: 10.1111/j.1365-294X.2011.05142.x.

[91] S. Ashraf, Q. Ali, Z. A. Zahir, S. Ashraf, and H. N. Asghar, "Phytoremediation: Environmentally sustainable way for reclamation of heavy metal polluted soils," Ecotoxicology and Environmental Safety, vol. 174. Academic Press, pp. 714-727, Jun. 15, 2019, doi: 10.1016/j.ecoenv.2019.02.068.

[92] P. K. Rai, "Heavy metal phyto-technologies from Ramsar wetland plants: green approach," https://doi.org/10.1080/02757540.2018.1501476, vol. 34, no. 8, pp. 786-796, Sep. 2018, doi: 10.1080/02757540.2018.1501476.

[93] X. Xie, L. Pu, Q. Wang, M. Zhu, Y. Xu, and M. Zhang, “Response of soil physicochemical properties and enzyme activities to long-term reclamation of coastal saline soil, Eastern China," Sci. Total Environ., vol. 607-608, pp. 1419-1427, Dec. 2017, doi: 10.1016/j.scitotenv.2017.05.185.

[94] S. Firmin et al., "Arbuscular mycorrhizal fungal inoculation protects Miscanthus $\times$ giganteus against trace element toxicity in a highly metal-contaminated site," Sci. Total Environ., vol. 527-528, pp. 91-99, Sep. 2015, doi: 10.1016/J.SCITOTENV.2015.04.116.

[95] D. Debiane et al., "Mycorrhization alleviates benzo[a]pyrene-induced oxidative stress in an in vitro chicory root model," Phytochemistry, vol. 70, no. 11-12, pp. 1421-1427, Jul. 2009, doi: 10.1016/J.PHYTOCHEM.2009.07.002.

[96] D. G. Karpouzas et al., "Effects of nicosulfuron on the abundance and diversity of arbuscular mycorrhizal fungi used as indicators of pesticide soil microbial toxicity," Ecol. Indic., vol. 39, pp. 44-53, Apr. 2014, doi: 10.1016/j.ecolind.2013.12.004.

[97] C. Merlin et al., "Characterization of chlordecone-tolerant fungal populations isolated from long-term polluted tropical volcanic soil in the French West Indies," Environ. Sci. Pollut. Res., vol. 21, no. 7, pp. 4914-4927, 2014, doi: 10.1007/s11356-0131971-8.

[98] E. Campagnac et al., "Arbuscular mycorrhiza partially protect chicory roots against oxidative stress induced by two fungicides, fenpropimorph and fenhexamid," Mycorrhiza 2009 203, vol. 20, no. 3, pp. 167-178, Sep. 2009, doi: 10.1007/S00572009-0267-9.

[99] N. Z. Sosibo, P. Muchaonyerwa, L. Visser, A. Barnard, E. Dube, and T. J. Tsilo, “Soil fertility constraints and yield gaps of irrigation wheat in South Africa," S. Afr. J. Sci., vol. 113, no. 1-2, pp. 1-9, Jan. 2017, doi: 10.17159/SAJS.2017/20160141.

[100] K. R. Sheetal, S. D. Singh, A. Anand, and S. Prasad, "Heavy metal accumulation and effects on growth, biomass and physiological processes in mustard," Indian J. Plant Physiol., vol. 21, no. 2, pp. 219-223, Jun. 2016, doi: 10.1007/s40502-0160221-8.

[101] A. Schützendübel and A. Polle, "Plant responses to abiotic stresses: heavy metal-induced oxidative stress and protection by mycorrhization," J. Exp. Bot., vol. 53, no. 372, pp. 1351-1365, May 2002, doi: 10.1093/JEXBOT/53.372.1351.

[102] M. Miransari, “Arbuscular Mycorrhizal Fungi and Heavy Metal Tolerance in Plants," Arbuscular Mycorrhizas Stress Toler. Plants, pp. 147-161, Apr. 2017, doi: 10.1007/978-981-10-4115-0_7.

[103] A. Javaid, "Importance of Arbuscular Mycorrhizal Fungi in Phytoremediation of Heavy Metal Contaminated Soils," Proc. Natl. Acad. Sci. India Sect. B - Biol. Sci., vol. 80, no. PART 2, pp. 125-141, Apr. 2011, doi: 10.1007/978-94-007-1914-9_5.

[104] M. C. González-Chávez, R. Carrillo-González, S. F. Wright, and K. A. Nichols, “The role of glomalin, a protein produced by arbuscular mycorrhizal fungi, in sequestering potentially toxic elements," Environ. Pollut., vol. 130, no. 3, pp. 317-323, Aug. 2004, doi: 10.1016/J.ENVPOL.2004.01.004.

[105] A. Vivas, I. Vörös, B. Biró, E. Campos, J. M. Barea, and R. Azcón, “Symbiotic efficiency of autochthonous arbuscular mycorrhizal fungus (G. mosseae) and Brevibacillus sp. isolated from cadmium polluted soil under increasing cadmium 
levels," Environ. Pollut., vol. 126, no. 2, pp. 179-189, Nov. 2003, doi: 10.1016/S0269-7491(03)00195-7.

[106] P. Cornejo, S. Meier, G. Borie, M. C. Rillig, and F. Borie, “Glomalin-related soil protein in a Mediterranean ecosystem affected by a copper smelter and its contribution to $\mathrm{Cu}$ and Zn sequestration," Sci. Total Environ., vol. 406, no. 1-2, pp. 154-160, Nov. 2008, doi: 10.1016/j.scitotenv.2008.07.045.

[107] A. Seguel, J. R. Cumming, K. Klugh-Stewart, P. Cornejo, and F. Borie, "The role of arbuscular mycorrhizas in decreasing aluminium phytotoxicity in acidic soils: A review," Mycorrhiza, vol. 23, no. 3. Springer Verlag, pp. 167-183, Apr. 01, 2013, doi: 10.1007/s00572-013-0479-x.

[108] *, Erik J. Joner et al., "Rhizosphere Effects on Microbial Community Structure and Dissipation and Toxicity of Polycyclic Aromatic Hydrocarbons (PAHs) in Spiked Soil," Environ. Sci. Technol., vol. 35, no. 13, pp. 2773-2777, Jul. 2001, doi: 10.1021/ES000288S.

[109] Y. Teng et al., "Influence of arbuscular mycorrhiza and Rhizobium on phytoremediation by alfalfa of an agricultural soil contaminated with weathered PCBs: A field study," Int. J. Phytoremediation, vol. 12, no. 5, pp. 516-533, Jul. 2010, doi: $10.1080 / 15226510903353120$.

[110] A. A. Verdin Lounès-Hadj Sahraoui J Fontaine A Grandmougin-Ferjani R Durand, “Effects of anthracene on development of an arbuscular mycorrhizal fungus and contribution of the symbiotic association to pollutant dissipation," Mycorrhiza, vol. 16, pp. 397-405, 2006, doi: 10.1007/s00572-006-0055-8.

[111] Z. Wu, K. McGrouther, J. Huang, P. Wu, W. Wu, and H. Wang, “Decomposition and the contribution of glomalin-related soil protein (GRSP) in heavy metal sequestration: Field experiment," Soil Biol. Biochem., vol. 68, pp. 283-290, 2014, doi: 10.1016/j.soilbio.2013.10.010.

[112] B. Estrada et al., "Diversity of arbuscular mycorrhizal fungi in the rhizosphere of Asteriscus maritimus (L.) Less., a representative plant species in arid and saline Mediterranean ecosystems," J. Arid Environ., vol. 97, pp. 170-175, 2013, doi: 10.1016/j.jaridenv.2013.05.019.

[113] H. Huang, S. Zhang, X. quan Shan, B. D. Chen, Y. G. Zhu, and J. N. B. Bell, “Effect of arbuscular mycorrhizal fungus (Glomus caledonium) on the accumulation and metabolism of atrazine in maize (Zea mays L.) and atrazine dissipation in soil," Environ. Pollut., vol. 146, no. 2, pp. 452-457, Mar. 2007, doi: 10.1016/J.ENVPOL.2006.07.001.

[114] R. Krishnamoorthy, C.-G. Kim, P. Subramanian, K.-Y. Kim, G. Selvakumar, and T.-M. Sa, “Arbuscular Mycorrhizal Fungi Community Structure, Abundance and Species Richness Changes in Soil by Different Levels of Heavy Metal and Metalloid Concentration," 2015, doi: 10.1371/journal.pone.0128784.

[115] S. E. D. HASSAN, E. BOON, M. ST-ARNAUD, and M. HIJRI, “Molecular biodiversity of arbuscular mycorrhizal fungi in trace metal-polluted soils," Mol. Ecol., vol. 20, no. 16, pp. 3469-3483, Aug. 2011, doi: 10.1111/J.1365-294X.2011.05142.X.

[116] M. Miransari, "Arbuscular mycorrhizal fungi and heavy metal tolerance in plants," in Arbuscular Mycorrhizas and Stress Tolerance of Plants, Springer Singapore, 2017, pp. 147-161.

[117] M. J. Mohammad, S. R. Hamad, and H. I. Malkawi, "Population of arbuscular mycorrhizal fungi in semi-arid environment of Jordan as influenced by biotic and abiotic factors," J. Arid Environ., vol. 53, no. 3, pp. 409-417, Mar. 2003, doi: 10.1006/jare.2002.1046.

[118] K. H. Kim, E. Kabir, and S. A. Jahan, "Exposure to pesticides and the associated human health effects," Science of the Total Environment, vol. 575. Elsevier B.V., pp. 525-535, Jan. 01, 2017, doi: 10.1016/j.scitotenv.2016.09.009.

[119] L. A. Souza, S. A. López Andrade, S. C. Ribeiro Souza, and M. A. Schiavinato, “Evaluation of Mycorrhizal Influence on the 
Development and Phytoremediation Potential of Canavalia Gladiata in Pb-Contaminated Soils," Int. J. Phytoremediation, vol. 15, no. 5, pp. 465-476, 2013, doi: 10.1080/15226514.2012.716099.

[120] R. CARRENHO, S. F. B. TRUFEM, and V. L. R. BONONI, “Arbuscular mycorrhizal fungi in Citrus sinensis/C. limon treated with Fosetyl-Al and Metalaxyl,” Mycol. Res., vol. 102, no. 6, pp. 677-682, 1998, doi: 10.1017/S0953756297005649.

[121] S. Bedini, A. Turrini, C. Rigo, E. Argese, and M. Giovannetti, "Molecular characterization and glomalin production of arbuscular mycorrhizal fungi colonizing a heavy metal polluted ash disposal island, downtown Venice," Soil Biol. Biochem., vol. 42, no. 5, pp. 758-765, May 2010, doi: 10.1016/J.SOILBIO.2010.01.010.

[122] V. K. Verma, S. Tewari, and J. P. N. Rai, "Ion exchange during heavy metal bio-sorption from aqueous solution by dried biomass of macrophytes," Bioresour. Technol., vol. 99, no. 6, pp. 1932-1938, 2008, doi: 10.1016/j.biortech.2007.03.042.

[123] X. Guo and J. Gong, “Differential effects of abiotic factors and host plant traits on diversity and community composition of root-colonizing arbuscular mycorrhizal fungi in a salt-stressed ecosystem.," Mycorrhiza, vol. 24, no. 2, pp. 79-94, 2014, doi: 10.1007/s00572-013-0516-9.

[124] M. M. Alguacil, M. P. Torres, E. Torrecillas, G. Díaz, and A. Roldán, "Plant type differently promote the arbuscular mycorrhizal fungi biodiversity in the rhizosphere after revegetation of a degraded, semiarid land," Soil Biol. Biochem., vol. 43, no. 1, pp. 167-173, 2011, doi: 10.1016/j.soilbio.2010.09.029. 